\title{
A Child with Severe Paraesthesia due to Pyrethroid Exposure: Successful Treatment with Topical Vitamin E
}

\author{
Piretroid Temasına Bağlı Ciddi Parestezisi Olan Bir Çocuk Olgu: Topikal Vitamin E ile \\ Başarılı Bir Tedavi
}

\author{
(D) Aykut Çağlar¹, (D) Anıl Er¹, (D) Emel Ulusoy¹, (D) Fatma Akgül1, (D) Dorukhan Besin², (D) Hurşit Apa1 \\ ${ }^{1}$ Dr. Behçet Uz Pediatric Diseases and Surgery Training and Research Hospital, Clinic of Child Emergency, Izmir, Turkey \\ 2Dr. Behçet Uz Pediatric Diseases and Surgery Training and Research Hospital, Clinic of Child Health and Diseases, Izmir, Turkey
}

\section{Abstract}

Pyrethroids are one of the most common insecticides and have been known as safe household insecticides. They are highly toxic for insects whereas they are low in toxicity for mammals. Poisoning syndromes occur via oral, dermal or respiratory exposure. Dermal paraesthesia is the most common symptom in cases of unintentional dermal exposure. Although mild dermal paraesthesia cases are commonly seen after occupational exposure, severe cases are rare in the literature. Thus, emergency physicians may have difficulties in terms of managing these patients. Here, we report a child with diffuse paraesthesia and agitation after 24 hours from insecticide exposure. The patient was well treated with topical vitamin E in our pediatric emergency department.

Keywords: Alpha-tocopherol, child, cyhalothrin, paraesthesia, pyrethrins

\section{Öz}

Piretroidler, yaygın şekilde kullanılan ve güvenli olarak bilinen ev içi böcek ilaçlarıdır. Memeliler için düşük toksik etki gösterirken, böcekler için yüksek düzeyde toksiktirler. Zehirlenme oral, deri veya solunum yolu ile maruziyet sonrasında ortaya çıkar. Parestezi, deri yolu ile maruziyet sonrasında görülen en yaygın semptomdur. Hafif parestezi olguları mesleki maruziyetten sonra sıklıkla görülmekle birlikte, literatürde ciddi olgular nadirdir, bu nedenle acil hekimler bu hastaların yönetiminde sıkıntı yaşayabilmektedirler. Burada çocuk acil servisimizde böcek ilacına maruz kaldıktan 24 saat sonra yaygın parestezi ve ajitasyonu olan ve topikal E vitamini ile başarılı şekilde tedavi edilmiş bir çocuğu sunuyoruz.

Anahtar Kelimeler: Alfa-tokoferol, çocuk, sihalotrin, parestezi, piretrinler

\section{Introduction}

Cases of poisoning caused by pesticides have commonly been seen. Pyrethrum and its derivatives have been known as safe insecticides to be used in the household settings because of their relatively selective toxicity for insects and low toxicity for mammals. ${ }^{1}$ Pyrethroids are divided into two subtypes, type 1 and type 2, where each type causes distinct Poisoning syndromes called type 1 and type 2 Poisoning syndrome, respectively, with different clinical manifestations (Table 1). ${ }^{2}$ Although systemic symptoms of these syndromes are rare, they can occur after exposure to the insecticides via the oral, dermal or respiratory route in cases of improper use or inadequate safety precautions. Paraesthesia is the most common symptom in cases of unintentional dermal exposure. ${ }^{2}$ Few reports are available in the literature. Thus, emergency physicians may have difficulties in terms of managing these patients. Here, we report a child admitted to our PED with diffuse paraesthesia and agitation after 24 hours from insecticide exposure.

\section{Case Report}

A seven-year-old boy was admitted to the PED with diffuse paraesthesia and agitation. On general assessment, he was highly agitated because of severe burning and itching sensation. His breathing and skin colour were normal. On physical examination, the heart rate was 95/min; blood

Yazışma Adresi/Address for Correspondence: Aykut Çağlar, Dr. Behçet Uz Pediatric Diseases and Surgery Training and Research Hospital, Clinic of Child Emergency, İzmir, Turkey E-posta: aykutcaglar@gmail.com ORCID ID: orcid.org/0000-0002-2805-5420

Geliş Tarihi/Received: 27.03.2019 Kabul Tarihi/Accepted: 16.06.2019 
Table 1. The types of pyrethroid poisoning syndromes ${ }^{5}$

Type $1(\mathrm{~T})$ poisoning

Type 1 pyrethroids

Severe fine tremor

Pyrethrin

Marked reflex hyperexcitability

Allethrin

Sympathetic activation

Tetramethrin

Paraesthesia

Resmethrein

Phenothrin

Permethrin

\begin{tabular}{ll} 
Type $\mathbf{2}(\mathrm{CS})$ poisoning & Type $\mathbf{2}$ pyrethroids \\
Profuse watery salivation & Cypermethrin \\
Coarse tremor & Deltamethrin \\
\hline Increased extensor tone & Fenvalerate \\
Moderate reflex hyperexcitability & Cyhalothrin \\
Seizures & \\
Paraesthesia & \\
T and CS poisoning & Fenpropathrin* \\
& Cyphenothrin* \\
* These derivatives cause an intermediate syndrome. & \\
CS: & \\
\hline
\end{tabular}

pressure, 105/55 mmHg; respiratory rate, 22/min; oxygen saturation on room air, 99\%. There was no additional pathological finding except for the paraesthesia. Erythema and oedema were not present. In his medical history, it was noted that the child had had skin contact with a pyrethroid insecticide, which has lambda-cyhalothrin as an active ingredient, in the last 24 hours. The burning sensation started around the eyes and spread all over the face three hours after the exposure. He had been admitted to another PED with these symptoms. Oral cetirizine was prescribed, but there was no improvement. The paraesthesia has increased due to several factors, such as contact with wind, sunlight and pool water. As a result, the patient was admitted to our PED with highly increased and spread burning sensation all over the body.

Although antihistaminic (pheniramine with a dosage of 1 $\mathrm{mg} / \mathrm{kg}$ ) and steroid (prednisolone with a dosage of $1 \mathrm{mg} /$ $\mathrm{kg}$ ) treatments were administered intravenously, regression was not observed. We decided to apply topical vitamin E after searching the literature. The regression of the symptoms was noticeable within five minutes and the patient fully recovered within 30 minutes. On follow-up, the patient had no symptoms and was discharged after 24 hours.

\section{Discussion}

Pyrethroids are the most commonly used household insecticides since the 1970s. Because of their mechanisms of action, they are highly selective for insects whereas they have low selectivity for mammalian organisms. ${ }^{1,2}$ They directly affect the sodium voltage channels and extend the time constant, which is usually 0.5 ms. So, they cause an incoordination of skeletal and heart muscles and salivary glands. If the time constant is shorter than $10 \mathrm{~ms}$, type 1 poisoning syndrome is seen; longer time constants cause type 2 poisoning syndrome. Although the clinical pictures of these two types of poisoning syndromes are different, if the time constant is between 6 and $10 \mathrm{~ms}$, it is called an intermediate syndrome. ${ }^{3}$

Paraesthesia is one of the polyneuropathy signs and may occur due to various systemic diseases particularly in adult population, but some drugs can cause acute paraesthesia. ${ }^{4}$ It is also the most common symptom in both types 1 and 2 poisoning syndromes. ${ }^{2}$ Although paraesthesia due to occupational contact was reported, up to our knowledge, there is only one child in the literature. ${ }^{5}$ Miyamoto et al. ${ }^{6}$ defined the characteristic features of paresthesia as follows: being limited to the contact region, starting in a few hours after contact and lasting at least 24 hours, and being aggravated by sunlight, warm air and wind. The histopathological changes, oedema and erythema were not present because there was no inflammatory reaction. Moreover, topical creams containing vitamin $E$, mineral oils, vitamins $A$ and $D$ and benzocaine had a positive effect on relieving of paraesthesia. In concordance with literature, the paraesthesia in our patient had started at the periorbital area and spread all over the body after intensive contact with pool water and sunlight.

When treating paraesthesia, creams containing vitamin $E$, benzocaine, mineral oils, or vitamins $A$ and $D$ are effective whereas zinc oxide, indomethacin or diphenhydramine containing ones are not. ${ }^{7}$ Although the mechanism of action of vitamin E is obscure, Song et al. ${ }^{8}$ reported that the alphatocopherol selectively blocks the sodium voltage channels which were induced by pyrethroids. Our patient showed no response to pheniramine and steroid treatments whereas his symptoms totally disappeared on applying topical vitamin $E$, in concurrence with this data.

In conclusion, pyrethroids are accepted as safe insecticide agents for household usage despite the fact that they may cause severe systemic effects. Emergency physicians should keep in mind that paraesthesia may result from pyrethroid exposure and they should consider topical vitamin E as an effective alternative treatment.

\section{Ethics}

Informed Consent: The written consent was obtained.

Peer-review: Internally and externally peer reviewed.

\section{Authorship Contributions}

Surgical and Medical Practices: A.Ç., A.E., H.A. Concept: A.Ç., A.E., H.A., Design: A.Ç., A.E., E.U., Data Collection or Processing: A.Ç., D.B., Analysis or Interpretation: A.Ç. 
Literature Search: A.Ç., F.A., E.U., Writing: A.Ç., E.U, F.A.,A.E.

Conflict of Interest: No conflict of interest was declared by the authors.

Financial Disclosure: The authors declared that this study received no financial support.

\section{References}

1. Fetoui H, Garoui el M, Zeghal N. Lambda-cyhalothrin-induced biochemical and histopathological changes in the liver of rats: ameliorative effect of ascorbic acid. Exp Toxicol Pathol. 2009;61:189-96.

2. Ray DE, Forshaw PJ. Pyrethroid insecticides: poisoning syndromes, synergies, and therapy. J Toxicol Clin Toxicol. 2000;38:95-101.

3. Wright C, Forshaw P, Ray D. Classification of the actions of ten pyrethroid insecticides in the rat, using the trigeminal reflex and skeletal muscle as test systems. Pesticide Biochemistry and Physiology. 1988;30:79-86.

4. Hughes R. Investigation of peripheral neuropathy. BMJ (Clinical research ed). 2010;341:c6100.

5. Perkins A, Walters F, Sievert J, Rhodes B, Morrissey B, et al. Home Use of a Pyrethroid-Containing Pesticide and Facial Paresthesia in a Toddler: A Case Report. Int J Environ Res Public Health. 2016;13:829.

6. Miyamoto J, Kaneko H, Tsuji R, Okuno Y. Pyrethroids, nerve poisons: how their risks to human health should be assessed. Toxicol Lett. 1995;82-83:933-40.

7. Malley LA, Cagen SZ, Parker CM, Gardiner TH, van Gelder GA, et al. Effect of vitamin $E$ and other amelioratory agents on the fenvalerate-mediated skin sensation. Toxicol Lett. 1985;29:51-8.

8. Song JH, Narahashi T. Selective block of tetramethrin-modified sodium channels by (+/-)-alpha-tocopherol (vitamin E). J Pharmacol Exp Ther. 1995;275:1402-11. 